\title{
Refleksi, Representasi, dan Simulasi; Studi Kasus pada Pemberitaan Kompas TV dan Youtube Dunia Manji
}

\author{
Wahyu Setiawan ${ }^{1}$ \\ ${ }^{1}$ Program Studi Komunikasi Penyiaran Islam, Magister UIN Sunan Ampel Surabaya \\ ${ }^{1}$ wahyustiaw4n@gmail.com
}

\begin{abstract}
The reality of television and youtube in making news or information through verbal and visual language does not always represent a reflection of reality but can only be a representation, even a simulation. This study intends to describe a reflection, representation and simulation carried out by the media. This study uses a qualitative method, with the primary data source in the form of a Youtube KompasTV account and a secondary a Youtube Narasi Newsroom account. Data collection techniques used in this study were documentation techniques and data analysis using the Miles and Huberman model. The findings in this study that the reality presented by the media is not always a reflection, such as the news report by Kompas TV entitled Conditions Keeps Worsening, Anies Again Strictly Imposing PSBB in Jakarta The reality displayed by the media can be in the form of representations such as in the KompasTV news entitled Citizens Responses to the Re-Application of PSBB Volume II in DKI Jakarta, 3 Minister Jokowi Anies Baswedan The Jakarta PSBB Problem and media reality can be in the form of simulations such as in Dunia Manji's Youtube content with the title Can Return to normal? Covid Drug Has Been Found !!
\end{abstract}

Keywords: Media, Reality, Representation, Reflection, And Simulation.

\begin{abstract}
Abstrak
Realitas televisi maupun youtube dalam membuat pemberitaan ataupun informasi melalui bahasa verbal maupun visual tidak selalu mewakili refleksi dari realitas melainkan dapat hanya sebuah representasi bahkan bisa hanya sebuah simulasi. Penelitian ini hendak menggambarkan sebuah refleksi, representasi dan simulasi yang dilakukan oleh media. Penelitian ini menggunakan metode kualitatif, dengan sumber data primer berupa akun Youtube KompasTV dan sekunder berupa akun Youtube Narasi Newsroom. Teknik pengumpulan data yang dipakai dalam penelitian ini adalah teknik dokumentasi dan analisis data yang memanfaatkan model Miles dan Huberman. Temuan dalam penelitian ini realitas yang ditampilkan media tidak selalu suatu refleksi seperti pemberitaan Kompas TV yang berjudul Kondisi Terus Memburuk, Anies Kembali Berlakukan PSBB Ketat di Jakarta. Realitas yang ditampilkan oleh media dapat berupa representasi seperti pada berita KompasTV yang berjudul Tanggapan Warga Soal Penerapan Kembali PSBB Jilid II di DKI Jakarta, 3 Menteri Jokowi Sindir Anies Baswedan Soal PSBB Jakarta serta realitas media dapat berupa simulasi seperti pada konten Youtube Dunia Manji dengan judul Bisa Kembali Normal? Obat Covid Sudah Ditemukan!!
\end{abstract}

Kata Kunci: Media, Reality, Representasi, Refleksi, Dan Simulasi.

\section{Pendahuluan}

Media massa merupakan sesuatu yang tidak asing lagi dalam kehidupan manusia, baik kehidupan individu maupun kehidupan masyarakat. Dalam kehidupan manusia, media

Jurnal Kopis: Kajian Penelitian dan Pemikiran Komunikasi Penyiaran Islam

Volume 03, Issue 02, Februari 2021 
massa merupakan sarana yang digunakan untuk mendistribusikan informasi yang telah dihimpun, yang selanjutnya ditujukan kepada masyarakat. ${ }^{1}$

Melalui media massa, masyarakat dapat mengetahui berbagai informasi yang dapat digunakan untuk menjalani kehidupannya sebagaimana pandangan McQuail bahwa media massa memiliki peranan bagi kehidupan bermasyarakat, yang dijelaskannya dalam enam perspektif, yakni (1) media massa sebagai jendela yang membuat masyarakat bisa melihat dunia luar dan juga dapat digunakan untuk mengetahui beragam peristiwa, (2) media massa sebagai cermin yang menampilkan berbagai peristiwa yang ada di masyarakat, (3) media massa merupakan penyeleksi peristiwa mana saja yang ada di masyarakat yang perlu untuk diberikan perhatian dan mana saja peristiwa yang ada di masyarakat yang tidak perlu untuk diberikan perhatian, (4) media massa dapat memberikan petunjuk bagi masyarakat atas berbagai ketidakpastian yang dialami dengan memberikan alternatif-alternatif informasi, (5) media massa dengan informasi yang diberikan kepada masyarakat maka memungkinkan terbentuk forum yang di dalamnya dapat terjadi suatu umpan balik, (6) media massa dapat menciptakan komunikasi yang interaktif. ${ }^{2}$ Informasi yang disebarluaskan oleh media massa dapat berwujud berita, opini, hiburan dan lain sebagainya. Berita sebagai salah satu produk dari media massa sangat diperlukan bagi masyarakat baik untuk memperbarui informasi maupun digunakan untuk petunjuk dalam menjalani kehidupannya.

Perkembangan teknologi telah melahirkan media baru yang seolah-olah menjadi pesaing bagi media tradisional dalam menyebarluaskan berita. Bila sebelumnya media massa seperti televisi, radio, koran dan sejenisnya yang mendominasi pemberitaan di masyarakat maka di era saat ini dengan kehadiran internet yang kemudian membuat semakin eksisnya media sosial. Melalui media sosial siapapun dapat terlibat untuk membuat dan menyebarluaskan berita. ${ }^{3}$

Youtube sebagai salah satu media sosial memiliki beberapa fitur yakni khalayak dapat mencari dan memutar berbagai video, mengunggah video, mengunduh video, berlangganan pada akun-akun yang ada di youtube, bahkan hingga live streaming (siaran langsung). ${ }^{4}$ Melalui fitur mengunggah video atua yang lebih dikenal dengan vlog, siaran langsung maka pemilik akun youtube bisa menyebarluaskan berita ataupun informasi dan dengan fitur mencari, memutar serta mengunduh video maka masyarakat sudah dapat memperoleh berita ataupun informasi dengan mudah.

Berita menurut Micthel V. Charnley dalam Asep Syamsul M. Romli merupakan suatu peristiwa yang berasal dari fakta, menyangkut kepentingan masyarakat dan dapat membuat pembaca menjadi tertarik. ${ }^{5}$ Pada dasarnya berita merupakan informasi yang disampaikan kepada masyarakat yang sumbernya berasal dari fakta. Dalam menampilkan fakta ini, berita menggunakan pesan. Pesan dapat berbentuk dalam tanda verbal maupun visual. Tanda verbal atau yang juga disebut dengan teks atau bahasa verbal bisa berwujud

\footnotetext{
${ }^{1}$ Burhan Bungin, Sosiologi Komunikasi, (Jakarta : Kencana Pranada Mediagroup, 2006), 72

${ }^{2}$ Denis McQuail, Mass Communication Theory (London: Sage Publication, 2000), 66.

${ }^{3}$ Rulli Nasrullah, Media Sosial (Bandung : Simbiosa Rekatama Media, 2015), 1 2013), 84

${ }^{4}$ Apriadi Tamburaka, Literasi Media Cerdas Bermedia Khalayak Media Massa (Jakarta : PT Raja Grafindo Persada,

${ }^{5}$ Asep Syamsul M Romli,Jurnalistik Terapan (Jakarta: Erlangga, 2006), 4
} 
dalam teks yang disampaikan secara lisan maupun teks yang disampaikan secara tertulis, sedangkan tanda visual atau yang juga disebut dengan teks atau bahasa visual dapat berwujud seperti gambar, foto, lukisan, ilustrasi atau rekaan yang dibuat oleh komputer. ${ }^{6}$ Sedangkan bahasa menurut Stuart Hall merupakan cerminan dari realitas, artinya bahasa merefleksikan realitas yang sebenarnya. ${ }^{7}$

Realitas televisi maupun youtube dalam membuat pemberitaan ataupun informasi melalui bahasa verbal maupun visual tidak selalu mewakili realitas melainkan dalam pandangan Jean Baudrillard, realitas yang terdapat dalam media merupakan ilusi atau bukan cerminan dari realitas sebab tanda yang digunakan tidak lagi mewakili tanda awal melainkan telah mewujud dalam tanda baru. ${ }^{8}$

Pemberitaan Kompas TV terkait kebijakan Anies Baswedan mengenai PSBB Jilid II DKI Jakarta memperlihatkan pada mulanya Kompas TV pada berita yang berjudul "Kondisi Terus Memburuk, Anies Kembali Berlakukan PSBB Ketat di DKI Jakarta" yang dipublikasi pada tanggal 9 September 2020. Dalam pemberitaan tersebut, Kompas TV menjelaskan bahwa Gubernur DKI Jakarta, yakni Anies Baswedan akan menerapkan kembali PSBB sebagaimana yang sudah dilakukan pada masa awal pandemi Covid-19 sebelumnya karena terdapat beberapa pertimbangan, seperti tingkat kematian yang terus meningkat dan hampir tidak adanya tempat tidur yang tersedia di rumah sakit, jika tidak kembali menerapkan PSBB seperti pada masa pandemi Covid-19 awal kali'. Pada pemberitaan ini, Kompas TV hanya menampilkan informasi sebagaimana yang disampaikan oleh Anies Baswedan.

Pada pemberitaan Kompas TV terkait kebijakan Anies Baswedan mengenai PSBB Jilid II DKI Jakarta selanjutnya mulai memperlihatkan adanya pemberitaan yang cenderung menyudutkan kebijakan Anies Baswedan tersebut sebagaimana yang terdapat pada pemberitaan Kompas TV yang berjudul Tanggapan Warga Soal Penerapan Kembali PSBB Jilid II di DKI Jakarta yang dipublikasi pada tanggal 11 September 2020. Dalam pemberitaan tersebut disampaikan bahwa dari 3 warga yang diwawancarai terkait akan diberlakukannya PSBB jilid II di DKI Jakarta, mereka menjelaskan bahwa kurang setuju dengan kebijakan tersebut karena akan bisa berdampak pada ekonomi mereka. ${ }^{10}$ Selanjutnya pada pemberitaan Kompas TV dengan judul "Tiga Menteri Jokowi Sindir Anies Baswedan Soal PSBB Jakarta” yang dipublikasi pada tanggal 11 September 2020. Diberitakan dalam tayangan ini bahwa terdapat tiga menteri Jokowi yang menyatakan bahwa PSBB ini membuat indeks saham menurun, PDB 50 persen dari konsumi dapat terganggu, industri akan mendapatkan tekanan lagi. ${ }^{11}$

Pemberitaan Kompas TV tersebut, yakni yang berjudul "Kondisi Terus Memburuk, Anies Kembali Berlakukan PSBB Ketat di DKI Jakarta" pada memiliki indikasi pada mulanya merupakan suatu refleksi namun dalam pemberitaan selanjutnya yakni yang berjudul "Tanggapan Warga Soal Penerapan Kembali PSBB Jilid II di DKI Jakarta”, "Tiga

\footnotetext{
${ }^{6}$ Yasraf Amir Piliang, "Semiotika Teks : Sebuah Pendekatan Analisis Teks", Jurnal Mediator vol.05 no. 02 (2004), 190

${ }^{7}$ Stuart Hall, Representation: Cultural Representation and Signifying Practices (London : Sage, 1995), 13

${ }^{8}$ Rulli Nasrullah, Media Sosial (Bandung : Simbiosa Rekatama Media, 2015), 28

"'Kondisi Terus Memburuk, Anies Kembali Berlakukan PSBB Ketat di DKI Jakarta." Video Youtube. Dikirim oleh Kompas TV, September 11, 2020. https://www.youtube.com/watch?v=vK7tae6vLgE

10 "Tanggapan Warga Soal Penerapan Kembali PSBB Jilid II di DKI Jakarta." Video Youtube, dikirim oleh Kompas TV, September 11, 2020. https://www.youtube.com/watch?v=ShH7L2ww5J0

11 "3 Menteri Jokowi Sindir Anies Baswedan Soal PSBB Jakarta", dikirim oleh Kompas TV, September 11, 2020. https://www.youtube.com/watch?v=nnhS-Z4GT2c
}

Jurnal Kopis: Kajian Penelitian dan Pemikiran Komunikasi Penyiaran Islam

Volume 03, Issue 02, Februari 2021 
Menteri Jokowi Sindir Anies Baswedan Soal PSBB Jakarta" memiliki indikasi mengarah pada suatu representasi, yakni media menggunakan bahasa untuk menjelaskan suatu realitas sesuai dengan cara pandangnya terhadap realitas tersebut, bahkan media mengkonstruksi makna melalui bahasa yang dipergunakannya. ${ }^{12}$

Konten Youtube Dunia Manji dengan judul "Bisa Kembali Normal? Obat Covid Sudah Ditemukan!!”. Namun, video dalam channel Dunia Manji ini akhirnya dihapus oleh pihak Youtube karena informasi yang disampaikan dianggap berbahaya di masa pandemi covid saat ini ${ }^{13}$. Dengan dihapusnya video tersebut, penulis tidak bisa merujuk langsung pada sumber tersebut melainkan penulis mengetahui adanya konten youtube Dunia Manji ini dari konten Youtube Narasi Newsroom dengan judul "Reaksi Ahli Biologi Molekuler yang Asli Nonton Video Diskusi Anji dan Hadi Pranoto". Dalam konten tersebut, Anji mewawancarai Hadi Pranoto yang dalam penjelasan Hadi Pranoto mengklaim bahwa dia telah menemukan obat Covid-19 ${ }^{14}$. Tayangan ini memperlihatkan adanya indikasi suatu simulasi, yakni adanya penciptaan suatu realitas yang tidak memiliki referensi realitas di dunia nyata, yang sebenarnya realitas yang diciptakan itu adalah realitas kedua yang referensinya adalah dirinya sendiri. ${ }^{15}$

Media merupakan sarana yang memiliki pengaruh besar untuk bisa membentuk pikiran masyarakat. Media bahkan mampu mempersatukan dan membentuk opini publik terhadap suatu peristiwa. ${ }^{16}$ Melalui informasi yang disebarkan media bisa membentuk pandangan publik bahkan hingga membentuk opini publik terhadap suatu perstiwa tertentu sehingga dengan adanya suatu representasi dan simulasi yang dilakukan oleh media maka hal yang semacam itu tentu media akan bisa membentuk pandangan publik hingga opini publik sesuai dengan yang diinginkan oleh media. Oleh karena itu, penulis tertarik untuk mengupas secara lebih jauh tentang bagaimana refleksi yang terdapat pada pemberitaan Kompas TV dengan judul berita yang sudah dibatasi di atas, yakni "Kondisi Terus Memburuk, Anies Kembali Berlakukan PSBB Ketat di DKI Jakarta" dan representasi pada pemberitaan Kompas TV yang berjudul yakni (1) "Tanggapan Warga Soal Penerapan Kembali PSBB Jilid II di DKI Jakarta”, (2) "Tiga Menteri Jokowi Sindir Anies Baswedan Soal PSBB Jakarta" serta simulasi pada konten Youtube Dunia Manji dengan judul "Bisa Kembali Normal? Obat Covid Sudah Ditemukan!!.?”

Dengan mengkaji mengenai refleksi, representasi pada pemberitaan Kompas TV dan simulasi pada konten Youtube Dunia Manji ini, tujuannya untuk mengetahui proses suatu refleksi, representasi dalam pemberitaan Kompas TV dan simulasi pada konten Youtube Dunia Manji.

1. Representasi

\footnotetext{
${ }^{12}$ Stuart Hall, Loc.cit.

13 https://inet.detik.com/cyberlife/d-5119424/alasan-youtube-hapus-video-anji-bareng-hadi-pranotom, diakses pada tanggal 29 November 2020

14 "Reaksi Ahli Biologi Molekuler yang Asli Nonton Video Diskusi Anji dan Hadi Pranoto.", dikirim oleh Narasi Newsroom, Agustus 4, 2020. https://www.youtube.com/watch?v=dXqAc5vYrEk

${ }^{15}$ Yasraf Amir Piliang, Op.cit., 51.

16 William Rivers, Media Massa dan Masyarakat Modern, (Jakarta : Prenada Media, 2004), 41
} 
Teori representasi sebagaimana yang dijelaskan oleh Stuart Hall memiliki dua konsep. Pertama, representasi mental adalah konsep mengenai suatu hal dalam pikiran setiap orang. Hal ini biasanya dinamakan juga dengan peta konseptual. Dalam representasi mental, akan membentuk konsep abstrak terhadap sesuatu. Kedua, representasi bahasa, dalam representasi bahasa ini memiliki peranan untuk mengkontruksi makna, manusia yang sebelumnya telah memiliki konsep abstrak terhadap sesuatu agar bisa dipahami oleh orang lain maka konsep abstrak tersebut harus diwujudkan dalam bentuk bahasa yang dipahami oleh orang lain. Dengan demikian pada bagian ini, konsep-konsep yang ada dalam benak pikiran akan terwakili dengan suatu tanda. ${ }^{17}$

Dalam teori representasi bila dikronologiskan maka setiap manusia yang hendak membuat tanda atau bahasa dalam berkomunikasi maka manusia akan terlebih dahulu memahami realitas yang ada, dari realitas ini maka manusia akan membentuk konsep dalam pikirannya terhadap realitas tersebut, misalnya realitas pohon maka manusia akan memiliki konsep dalam pikirannya mengenai pohon seperti tumbuhan berbatang keras dan besar. Dari konsep yang semacam ini maka manusia dalam berkomunikasi dengan orang lain maka manusia akan menyusun konsep tersebut menjadi suatu tanda atau bahasa yang bisa dipahami oleh manusia yang lain sehingga muncul lah tanda atau bahasa berupa teks pohon. Dari konsep dasar representasi ini maka terdapat tiga poin penting yakni realitas, konsep abstrak atas realitas, dan tanda atau bahasa.

Representasi merupakan teori yang memproduksi suatu makna dalam konstruksi sosial, yang oleh Stuart Hall representasi ini diperjelas melalui 3 teori representasi yakni

Teori yang pertama, dijelaskan dalam pendekatan reflektif yakni bahasa merupakan cermin dari realitas yang sebenarnya yang terdapat pada dunia. Dalam pendekatan ini bahasa merupakan pantulan sesuai realitas yang sebenarnya yang ada di dunia nyata.

Teori yang kedua, dijelaskan dalam pendekatan intensional yakni manusia dalam berkomunikasi akan menggunakan bahasa yang dipergunakan untuk menjelaskan sesuatu atau realitas sesuai dengan cara pandang yang dimiliki oleh manusia tersebut terhadap sesuatu atau realitas. Dalam pendekatan ini manusia menggunakan bahasa sesuai dengan realitas yang dipahami olehnya.

Teori yang ketiga, dijelaskan dalam pendekatan konstruksi yakni manusia melakukan konstruksi makna dengan menggunakan bahasa. Dalam pendekatan ini manusia sejak awal memang melakukan konstruksi makna melalui bahasa yang dipergunakan. ${ }^{18}$

2. Simulasi

Simulasi merupakan upaya menciptakan suatu realitas yang referensinya tidak ada di dunia nyata, referensinya justru berasal dari dirinya sendiri atau bisa

${ }^{17}$ Stuart Hall, Loc.cit.

${ }^{18}$ Stuart Hall

Jurnal Kopis: Kajian Penelitian dan Pemikiran Komunikasi Penyiaran Islam

Volume 03, Issue 02, Februari 2021 
disebut simulacrum of simulacrum. Bahasa atau tanda yang dipergunakan seolah-olah merefleksikan pada realitas yang sebenarnya padahal bahasa atau tanda tersebut merupakan realitas artifisial yakni realitas yang dibuat oleh teknologi simulasi. Hal ini pada tingkat tertentu membuat realitas artifisial tersebut menjadi tampak atau dipercaya sebagai kenyataan yang sebenarnya. Dalam kondisi ini maka tanda menjadi lebur dengan realitas, artinya melalui kecanggihan teknologi maka antara tanda dengan realitas tidak terdapat perbedaan lagi. ${ }^{19}$

Simulasi merupakan istilah yang dipergunakan oleh Jean Braudillard dalam menjelaskan hubungan antara produksi, komunikasi dengan konsumsi pada masyarakat kapitalis di dunia barat dengan ciri adanya overproduksi, overkomunikasi serta overkonsumsi yang ditampilkan melalui media, iklan, industri hiburan, supermarket, fashion dan lain-lain. Simulasi dalam masyarakat konsumer, realitas yang ditampakan tidak lagi memiliki kaitan dengan duplikasi dari substansi yang diduplikasi namun simulasi menciptakan model-model yang nyata tanpa ada asal usul realitasnya. Dalam simulasi referensi dari duplikasi yang dilakukan bukan lagi berasal dari realitas melainkan berasal dari fantasi. Dengan demikian, fantasi dengan disimulasikan maka akan tampak seakan-akan nyata sehingga tidak ada lagi perbedaan antara realitas dengan fantasi. Misalnya manusia dapat mengalami fantasi, halusinasi, dunia supranatural,science fiction, secara total hanya dengan melihat acara di televisi, film, arstitektur. ${ }^{20}$

Bagi Braudillard simulasi berbeda dengan representasi, bila dalam representasi, tanda dengan referensinya masih ada di dunia nyata sedangkan dalam simulasi, tanda sudah tidak ada lagi referensinya di dunia nyata. Dengan demikian, simulasi merupakan duplikat dari dirinya sendiri, duplikat dari fiksi, ilusi, nostalgia atau halusinasi. ${ }^{21}$

Dalam simulasi, khalayak bisa kehilangan realitas sebenarnya karena karena realitas sebenarnya telah tergantikan oleh realitas semu yang dibuat oleh media. Kesadaran khalayak yang hilang ini bisa terjadi karena media secara berkelanjutan menampilkan realitas yang semu sehingga khalayak seakan-akan tidak bisa membedakan antara yang nyata dengan realitas yang ada di depan layar. ${ }^{22}$ Contoh dalam media sosial, para pengguna media sosial bisa jadi merupakan simulasi karena dalam media sosial, identitas dapat berubah-ubah. Siapapun bisa menjadi orang lain dengan merubah hubungan perkawinan, jenis kelamin bahkan hingga foto profil. ${ }^{23}$

Tanda untuk sampai pada simulasi melalui empat perkembangan yakni

1. Tanda merupakan refleksi realitas

2. Tanda menyimpang dari realitas

3. Tanda menghilang dari realitas

\footnotetext{
${ }^{19}$ Yasraf Amir Piliang, Op.cit., 51

${ }^{20}$ Yasraf, h. 127-128

${ }^{21}$ Yasraf, h. 128

${ }^{22}$ Rulli Nasrullah, Op.cit., 28

${ }^{23}$ Rulli
} 
4. Tanda tidak lagi berhubungan dengan realitas apapun, tanda secara murni menjadi simulakrum. ${ }^{24}$

\section{Metode}

Penelitian ini menggunakan metode kualitatif, yakni penelitian yang dilakukan secara natural dan peneliti tidak mengadakan perlakuan. ${ }^{25}$ Sumber data yang digunakan adalah sumber data primer yang merupakan data yang didapatkan pengumpul data berasal langsung dari sumber data. ${ }^{26}$ Dengan sumber data berupa berita KompasTV dan akun Youtube dari narasi newsroom. Teknik pengumpulan datanya adalah dokumentasi dan teknik analisis datanya memakai model Miles dan Huberman.

\section{Hasil dan Pembahasan}

Dalam akun kompas TV di Youtube yang telah ditelusuri oleh penulis, terdapat beberapa pemberitaan yang ditemukan yang bisa memperlihatkan adanya suatu refleksi dan representasi. Dari beberapa pemberitaan tersebut, penulis mengambil satu video yang memperlihatkan adanya refleksi, yakni pada pemberitaan Kompas TV yang berjudul "Kondisi Terus Memburuk, Anies Kembali Berlakukan PSBB Ketat di DKI Jakarta" yang dipublikasi pada tanggal 9 September $2020 .^{27}$

Pemberitaan yang ditampilkan oleh Kompas TV dalam video tersebut, terdapat tanda atau bahasa verbal maupun visual. Dalam bahasa verbal baik teks maupun lisan, secara prinsip menjelaskan bahwa Anies Baswedan akan menerapkan kembali PSBB sebagaimana yang sudah dilakukan pada masa awal pandemi Covid-19 sebelumnya karena terdapat beberapa pertimbangan, seperti tingkat kematian yang meningkat terus-menerus dan minimnya jumlah tempat tidur untuk pasien di rumah sakit bila tidak kembali menerapkan PSBB seperti pada masa pandemi Covid-19 awal kali. ${ }^{28}$ Sedangkan dalam tanda atau bahasa visualnya terdapat Gubernur DKI Jakarta, yakni Anies Baswedan serta Wakil Gubernur DKI Jakarta, yakni Ahmad Riza Patria yang menyampaikan konferensi pers dan menyampaikan secara prinsip bahwa bahasa verbalnya sebagaimana yang disampaikan sebelumnya. Pemberitaan yang semacam ini tentu sesuai dengan pendekatan pendekatan reflektif yakni bahasa merupakan cermin dari realitas yang sebenarnya yang terdapat pada dunia. Dalam pendekatan ini bahasa merupakan pantulan sesuai realitas yang sebenarnya yang ada di dunia nyata. ${ }^{29}$ Selain itu, pemberitaan Kompas TV dengan judul tersebut juga sesuai dengan tahap perkembangan tanda yang dijelaskan dalam teori simulasi, yakni tanda merupakan refleksi realitas. ${ }^{30}$ Pemberitaan Kompas TV dalam judul tersebut merupakan suatu bentuk refleksi karena baik bahasa verbal teks dan tulis serta bahasa visualnya memang mencerminkan realitas yang sebenarnya yang ada di dunia nyata, sebagaimana pesan Anies Baswedan akan menerapkan kembali PSBB sebagaimana yang sudah dilakukan pada masa awal pandemi Covid-19 sebelumnya karena terdapat beberapa pertimbangan seperti tingkat kematian yang semakin tinggi dan ketersediaan tempat tidur di rumah sakit

${ }^{24}$ Yasraf Amir Piliang, Op.cit., 130

${ }^{25}$ Sugiyono, Metode Penelitian Kuantitatif, Kualitatif dan R\&D (Bandung: CV. Alfabeta, 8

${ }^{26}$ Sugiyono, h. 224.

${ }^{27}$ Youtube Kompas TV, September 11, 2020., Op.cit., https://www.youtube.com/watch?v=vK7tae6vLgE

${ }^{28}$ Youtube Kompas

${ }^{29}$ Stuart Hall, Loc.cit.

${ }^{30}$ Yasraf Amir Piliang, Loc.cit.

Jurnal Kopis: Kajian Penelitian dan Pemikiran Komunikasi Penyiaran Islam

Volume 03, Issue 02, Februari 2021 
yang sudah hampir tidak mencukupi bila tidak kembali menerapkan PSBB seperti pada masa pandemi Covid-19 awal kali. ${ }^{31}$ Pesan tersebut memang nyata ada dalam video pemberitaan dan sesuai juga dengan bahasa visual yakni Anies Baswedan yang menyampaikan bahasa verbal tersebut.

Pada pemberitaan Kompas TV yang berjudul Tanggapan Warga Soal Penerapan Kembali PSBB Jilid II di DKI Jakarta yang dipublikasi pada tanggal 11 September 2020. ${ }^{32}$

Dalam pemberitaan ini terdapat bahasa visual yang menampilkan 3 warga yang diwawancarai dengan bahasa verbal yang disampaikan yakni pertama warga bernama Dewi, dia menjelaskan bahwa dirinya pribadi kurang setuju dengan PSBB jilid II tetapi kalau sudah diatur bagaimana lagi, dia sebenarnya ingin cepat selesai saja covid ini agar bisa kembali normal, karena akibat PSBB berdampak bagi ekonominya yang merupakan pedagang kecil. Ke dua warga bernama Junaidi, tanggapannya terhadap PSBB jilid II ini yakni terhadap ekonomi cukup tertanggu dengan PSBB ini. Ke tiga warga bernama Ade Irma, tanggapannya terkait PSBB jilid II ini adalah terganggu kalau ada PSBB karena berdampak pada ekonomi karena kalau ada PSBB maka dia tidak bisa bekerja. ${ }^{33}$

Pemberitaan tersebut merupakan suatu representasi yakni teori yang memproduksi suatu makna dalam konstruksi sosial yang dijelaskan lagi dalam pendekatan konstruksi yakni manusia melakukan konstruksi makna dengan menggunakan bahasa. Dalam pendekatan ini manusia sejak awal memang melakukan konstruksi makna melalui bahasa yang dipergunakan. ${ }^{34}$ Pada pemberitaan ini Kompas TV hanya memberitakan tiga warga yang bila dipahami dari bahasa verbalnya dapat dipahami maknanya bahwa mereka keberatan bila dilakukan PSBB Jilid II DKI Jakarta sebab akan berdampak pada ekonomi mereka dan lebih jauh lagi maka sebenarnya maknanya kebijakan PSBB Jilid II DKI Jakarta tidak merugikan ekonomi masyarakat. Tentu bila hal yang seperti ini saja yang ditampilkan maka ini tidak mencerminkan realitasnya melainkan hanya menampilkan sebagian realitasnya dengan mengkonstruksi makna melalui bahasa verbal yang disampaikan oleh tiga warga tersebut. Padahal bila ingin menampilkan tanggapan yang lebih menyeluruh dengan realitasnya maka tentu tidak cukup dengan tiga tanggapan warga tersebut.

Pada pemberitaan Kompas TV yang berjudul "Tiga Menteri Jokowi Sindir Anies Baswedan Soal PSBB Jakarta yang dipublikasikan pada tanggal 11 September 2020, ${ }^{35}$ terdapat bahasa visual, yakni ditampilkannya gambar tiga menteri Jokowi: Menteri Bidang Perekonomian Airlangga Hartanto, Menteri Perdagangan Agus Suparmanto, dan Menteri Perindustrian Agus Gumiwang. Bahasa verbal dari masing-masing tiga menteri tersebut, yakni Menteri Bidang Perekonomian Airlangga Hartanto menyebutkan bahwa anjloknya IHSH pada Kamis, 10 November 2020 karena pengumuman Gubernur DKI pada satu hari sebelumnya, yakni PSBB jilid II DKI Jakarta. Dalam berita tersebut, dikatakan bahwa anjloknya IHSH dilihat dari indeksnya yang menurun di bawah 5.000. Selain itu, Agus Suparmanto sebagai Menteri Perdagangan memberikan peringatan atas risiko dari PSBB

\footnotetext{
${ }^{31}$ Youtube Kompas TV, September 11, 2020., Op.cit., https://www.youtube.com/watch?v=vK7tae6vLgE.

32 “"Tanggapan Warga Soal Penerapan Kembali PSBB Jilid II di DKI Jakarta.”, Loc.cit.

${ }^{33}$ Ibid.

${ }^{34}$ Stuart Hall, Loc.cit.

${ }^{35}$ Youtube Kompas TV, September 11, 2020. Op.cit., https://www.youtube.com/watch?v=nnhS-Z4GT2c
} 
DKI Jakarta. Menurutnya, hal ini karena 50\% PDB merupakan konsumsi. Berdasarkan fakta ini, ia menekankan bahwa ketidaklancaran distribusi karena PSBB tersebut juga bisa mengganggu PDB negara. Lebih lanjut, Menteri Perindustrian juga menyampaikan bahwa saat ini kerjasama bersama pihak-pihak masih dapat dijalin sehingga membuka jalur distribusi. Hal ini diharapkan agar supply chain masih tetap stabil, terlebih bagi banyak industri. Apabila masih stabil, harapannya tidak berdampak pada pemutusan hubungan kerja para karyawan.

Selain itu, Menteri Perindustrian juga menyoroti keputusan Jakarta kembali PSBB. Ia melihat industri saat ini sedang berusaha bangkit, lalu menjadi khawatir menerima represi akibat adanya PSBB. Namun, pengutamaan pada faktor kesehatan masyarakat menjadi hal yang tidak bisa diabaikan oleh pemerintah. Ia juga menyampaikan bahwa beredar pendapat yang menilai hal ini terlalu berambisi, tetapi program ini harus terus dijalankan. Dengan catatan, apabila PSBB dilaksanakan dengan ketat kembali, tidak sekadar di wilayah DKI Jakarta, tetapi juga di daerah lain, maka program substitusi impor akan terpengaruh. ${ }^{36}$

Pemberitaan tersebut merupakan suatu representasi: teori yang memproduksi suatu makna dalam konstruksi sosial. Dalam pendekatan konstruksi, manusia membentuk konstruksi makna dengan menggunakan bahasa. Dalam pendekatan ini, manusia sejak awal memang melakukan konstruksi makna melalui bahasa yang digunakan. ${ }^{37}$ Melalui bahasa verbal yang disampaikan dalam pemberitaan ini, yang tergambar dari judul berita ini, yakni "Tiga Menteri Jokowi Sindir Anies Baswedan soal PSBB Jakarta" yang selanjutnya diperjelas dalam tanggapan tiga Menteri Jokowi terkait PSBB, yakni Menteri Bidang Perekonomian Airlangga Hartanto, Menteri Perdagangan Agus Suparmanto, dan Menteri Perindustrian Agus Gumiwang dalam pernyataannya yang telah dijabarkan dalam paragraf di atas. ${ }^{38}$ Dari pemberitaan mengenai penjelasan ketiga menteri tersebut, makna yang dikonstruksi adalah kebijakan Anies Baswedan yang memberlakukan PSBB akan membuat ekonomi menjadi sulit dengan adanya gejala IHSG yang turun pasca pengumuman PSBB lagi. Hal ini juga dapat mempengaruhi PDB RI dan menekan sektor industri yang saat ini sedang bergeliat. Dengan menampilkan berita tiga Menteri Jokowi yang memberikan sindiran terhadap PSBB yang akan diberlakukan Anies Baswedan, hal ini jelas hendak mengkonstruksi makna dan berita yang ditampilkan tidaklah menyeluruh karena untuk menilai kebijakan PSBB secara keseluruhan, tentu harus ada pihak lain yang menilai dan tidak hanya dengan pendekatan ekonomi sehingga bisa diketahui realitas secara menyeluruhnya.

Konten Youtube Dunia Manji yang berjudul "Bisa Kembali Normal? Obat Covid Sudah Ditemukan!!”. Karena sumber utama video ini telah dihapus oleh Youtube, analisis dilakukan dengan menggunakan konten Youtube Narasi Newsroom dengan judul "Reaksi Ahli Biologi Molekuler yang Asli Nonton Video Diskusi Anji dan Hadi Pranoto". 39

Dalam konten terksebut terdapat bahasa visual yang menampilkan Anji dan Hadi Pranoto dan bahasa verbal Anji sebagai pembawa acara bertanya-tanya terkait covid dan temuan dari Hadi Pranoto terkait obat covid-19. Selain itu, terdapat bahasa verbal Hadi Pranoto yang menjelaskan mengenai beberapa hal yakni temuannya merupakan obat covid-

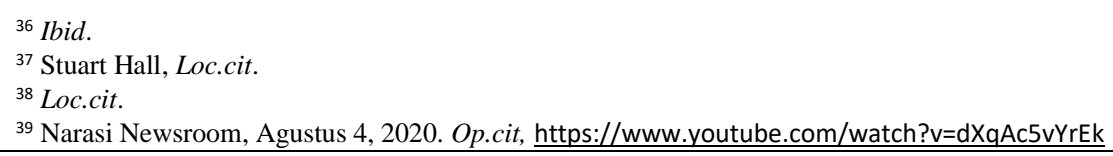

Jurnal Kopis: Kajian Penelitian dan Pemikiran Komunikasi Penyiaran Islam Volume 03, Issue 02, Februari 2021 
19, obat ini merupakan antibody covid-19 yang bisa menyembuhkan atau mencegah. Kalau vaksin disuntikkan, kalau ini diminum, obat yang dimilikinya bisa membuat sembuh dari covid 2-3 hari, covid virusnya sebenarnya sama dengan sars, mers hanya beda dosisnya, ilmuwan belum berani menyebut bahwa obat ini sebagai vaksi covid-19 semakin hari covid ini semakin kuat, di atas 350 derajat virus ini baru mati, virusnya ada tipe A,B,C,D, teknologi diagnostik covid hanya Rp 10ribu. Dalam konten tersebut akan terlihat simulasinya, yakni sebagaimana yang dipahami simulasi merupakan upaya menciptakan suatu realitas yang referensinya tidak ada di dunia nyata, referensinya justru berasal dari dirinya sendiri.. Bahasa atau tanda yang dipergunakan seolah-olah merefleksikan pada realitas yang sebenarnya padahal bahasa atau tanda tersebut merupakan realitas artifisial yakni realitas yang dibuat oleh teknologi simulasi. Hal ini pada tingkat tertentu membuat realitas artifisial tersebut menjadi tampak atau dipercaya sebagai kenyataan yang sebenarnya. Dalam kondisi ini maka tanda menjadi lebur dengan realitas, artinya melalui kecanggihan teknologi maka antara tanda dengan realitas tidak terdapat perbedaan lagi. ${ }^{40}$

Bahasa verbal yang dijelaskan oleh Hadi Pranoto sebenarnya tidak mewakili realitas apapun. Hal ini bisa ditelusuri dari bahwa temuannya merupakan obat covid-19, nyatanya pada kesempatan lainnya diakui oleh Hadi bahwa itu hanyalah herbal, lalu antibody covid-19 yang bisa menyembuhkan atau mencegah. Kalau vaksin disuntikkan, kalau ini diminum. Nyatanya ini dibantah oleh Pakar Biologi Molekuler Ahmad Utomo bahwa tidak ada antibodi yang dimakan karena nanti pasti hancur ketika berada di lambung. Obat yang dimilikinya bisa membuat sembuh dari covid 2-3 hari, hal ini dibantah oleh Ahmad Utomo karena perawatan pasien bisa 2-3 minggu. Covid virusnya sebenarnya sama dengan sars, mers hanya beda dosisnya. Hal ini dibantah oleh Ahmad Utomo bahwa virus covid-19 dengan sars, mers itu beda jauh sekali sehingga bukan masalah dosis tetapi memang makhluknya berbeda. Di atas 350 derajat virus ini baru mati, pernyataan ini juga dibantah oleh Ahmad Utomo, yakni virus ini bisa mati pada suhu 100 derajat. Teknologi diagnostik covid hanya Rp10ribu, yang kemudian kembali dibantah oleh Ahmad Utomo bahwa teknologi diagnostik di dunia hampir sama sehingga tidak ada teknologi semurah itu. ${ }^{41}$ Dalam analisis ini terlihat bahwa yang ditampilkan dalam konten Youtube Dunia Manji yang berjudul Bisa Kembali Normal? Obat Covid Sudah Ditemukan!! merupakan suatu simulasi artinya tanda atau bahasa yang ditampilkan ternyata tidak sesuai dengan realitasnya sama sekali, justru referensinya sebenarnya adalah tanda atau bahasa yang ditampilkan dalam konten Youtube itu sendiri.

\section{Kesimpulan}

Realitas yang ditampilkan suatu media tidak selalu merupakan suatu refleksi artinya yang ditampilkan merupakan cerminan atau pantulan sesuai dengan realitasnya sebagaimana pemberitaan Kompas TV yang berjudul "Kondisi Terus Memburuk, Anies Kembali Berlakukan PSBB Ketat di DKI Jakarta”, melainkan realitas yang ditampilkan oleh media dapat berupa representasi artinya yang ditampilkan oleh media merupakan suatu

\footnotetext{
${ }^{40}$ Yasraf Amir Piliang, Op.cit., 51.
}

${ }^{41}$ Loc.cit.

Jurnal Kopis: Kajian Penelitian dan Pemikiran Komunikasi Penyiaran Islam Volume 03, Issue 02, Februari 2021 
konstruksi makna yang dilakukan dengan menggunakan bahasa. Artinya, konstruksi tersebut tidaklah mewakili keseluruhan realitasnya sebagaimana dalam pemberitaan Kompas TV yang berjudul "Tanggapan Warga Soal Penerapan Kembali PSBB Jilid II di DKI Jakarta" dan "Tiga Menteri Jokowi Sindir Anies Baswedan Soal PSBB Jakarta" serta realitas media dapat berupa simulasi yakni yang ditampilkan oleh media itu tidak memiliki referensi realitas di dunia nyata, referensinya adalah realitas yang ada dalam layar. Realitas simulasi yang semacam ini terdapat pada konten Youtube Dunia Manji dengan judul "Bisa Kembali Normal? Obat Covid Sudah Ditemukan!!’.

Realitas yang ditampilkan media ternyata bisa tidak hanya refleksi, tetapi bisa representasi hingga simulasi, maka saran penulis terkait persoalan semacam ini, yakni bagi pemerintah bisa memperkuat lagi terkait UU Pers sehingga pemberitaan media seharusnya bisa proporsional sehingga dapat menggambarkan realitas secara keseluruhannya. Selain itu, bagi masyarakat harus memiliki pengetahuan dengan terus dilakukan pendidikan kepada masyarakat untuk terus melakukan kroscek dan membaca berbagai informasi dari sumber yang berbeda sehingga nanti bisa mengetahui apakah ditampilkan oleh media sudah utuh ataukah sebagian dan apakah yang ditampilkan oleh media merupakan suatu kenyataan atau sebenarnya hanyalah simulasi.

\section{Daftar Pustaka}

Bungin, Burhan. Sosiologi Komunikasi. Jakarta : Kencana Pranada Media Group, 2006.

Hall, Stuart, Representation : Cultural Representation and Signinfying Pratices. London : Sage, 1995

McQuail, Denis, Mass Communication Theory.London: Sage Publication, 2000.

Nasrullah, Rulli, Media Sosial. Bandung: Simbiosa Rekatama Media, 2015

Piliang, Yasraf Amir, "Semiotika Teks: Sebuah Pendekatan Analisis Teks", Jurnal Mediator, vol.05 no. 02 (2004): 190

. Semiotika dan Hipersemiotika. Bandung: Matahari, 2012

Romli, Asep Syamsul M, Jurnalistik Terapan, Jakarta: Erlangga, 2006

Rivers, William. Dkk, Media Massa dan Masyarakat Modern. Jakarta : Prenada Media, 2004

Sugiyono, Metode Penelitian Kuantitatif, Kualitatif dan RひD. Bandung: CV. Alfabeta, 2011

Tamburaka, Apriadi, Literasi Media Cerdas Bermedia Khalayak Media Massa, Jakarta : PT Raja Grafindo Persada, 2013.

"Kondisi Terus Memburuk, Anies Kembali Berlakukan PSBB Ketat di DKI Jakarta." Video Youtube. Dikirim oleh Kompas TV, September 11, 2020. https://www.youtube.com/watch?v $={ }_{v} K 7$ tae6vLgE

“Tanggapan Warga Soal Penerapan Kembali PSBB Jilid II di DKI Jakarta." Video Youtube, dikirim oleh Kompas TV, September 11, 2020. https://www.youtube.com/watch?v=ShH7L2ww5J0

Jurnal Kopis: Kajian Penelitian dan Pemikiran Komunikasi Penyiaran Islam

Volume 03, Issue 02, Februari 2021 
"3 Menteri Jokowi Sindir Anies Baswedan Soal PSBB Jakarta”, dikirim oleh Kompas TV, September 11, 2020. https://www.youtube.com/watch?v=nnhS-Z4GT2c

"Reaksi Ahli Biologi Molekuler yang Asli Nonton Video Diskusi Anji dan Hadi Pranoto.", dikirim oleh Narasi Newsroom, Agustus 4, 2020. https://www.youtube.com/watch?v $=\mathrm{dXqAc5vYrEk}$ 